\title{
Jatropha cultivation in Malawi and Mozambique: impact on ecosystem services, local human well-being, and poverty alleviation
}

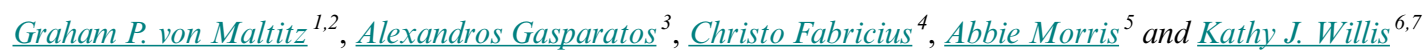

\begin{abstract}
Jatropha-based biofuels have undergone a rapid boom-and-bust cycle in southern Africa. Despite strong initial support by governments, donors, and the private sector, there is a lack of empirical studies that compare the environmental and socioeconomic impacts of Jatropha's two dominant modes of production: large plantations and smallholder-based projects. We apply a rapid ecosystem services assessment approach to understand the impact of two Jatropha projects that are still operational despite widespread project collapse across southern Africa: a smallholder-based project (BERL, Malawi) and a large plantation (Niqel, Mozambique). Our study focuses on changes in provisioning ecosystem services such as biofuel feedstock, food, and woodland products that can have important effects on human well-being locally. Qualitative information is provided for other regulating and cultural ecosystem services. Although at this stage no impact is tremendously positive or negative, both projects show some signs of viability and local poverty alleviation potential. However, their long-term sustainability is not guaranteed given low yields, uncertain markets, and some prevailing management practices.
\end{abstract}

Key Words: biofuels; ecosystem services; Jatropha; Malawi; Mozambique; smallholders

\section{INTRODUCTION}

Biofuels have been promoted in southern Africa since the mid-2000s for national energy security, rural development, and economic gains from export (Mitchell 2010, Gasparatos et al. 2013a, 2015, von Maltitz et al. 2014). Jatropha curcas L (Jatropha) has been the feedstock that has gathered the greatest attention from governments, donors, and the private sector (Romijn et al. 2014, Gasparatos et al. 2015). Jatropha is a shrub/small tree that produces seeds with high oil content (> 30\%; Henning 2009). Though toxic for humans and animals, Jatropha is suitable for the production of pure plant oil fuel and biodiesel (Lu 2009).

Enthusiasm for Jatropha was largely driven by numerous claims including the potential to obtain high oil yields (> $1600 \mathrm{~L} / \mathrm{ha}$ ), drought-hardiness, immunity to pests/diseases, and suitability to grow on marginal/degraded lands (Jongschaap et al. 2007). Subsequent studies confirmed that Jatropha is drought-hardy, but requires good soils, reasonably high rainfall, and good agricultural management to achieve optimum yields (Trabucco et al. 2010).

Despite this lack of agronomic knowledge, Jatropha was adopted across southern Africa for both large-scale commercial plantation- and smallholder-based production (von Maltitz and Setzkorn 2013). As early as 2008, 52 Jatropha projects were operational in southern Africa, with an estimated 111,000 ha planted (GEXSI 2008). However, the area actually planted may have been exaggerated (Locke and Henley 2013).

Eventually most Jatropha projects in Madagascar, Mozambique, Tanzania, and Zambia collapsed because of numerous interconnected reasons ranging from overoptimistic business plans, to low yields, time-lags in production, underestimated labor/maintenance/transport costs, lack of markets, changes in investor behavior following the 2008 financial crisis, lack of appropriate policy frameworks to regulate the biofuel sector, and institutional barriers posed by national governments (von Maltitz et al. 2014, Gasparatos et al. 2015). The actual challenges faced by Jatropha projects (Romijn et al. 2014) or the reasons behind their collapse (A. Ahmed, B. B. Campion, and A. Gasparatos, unpublished manuscript) can vary between projects (and often act synergistically) because of the different national policies, companies, modes of production, and environmental/social contexts within which Jatropha projects operate. However, despite this boom-and-bust cycle, there are some Jatropha projects that are still operational in southern Africa (von Maltitz et al. 2014).

Despite the large Jatropha expansion in the region, there is a lack of consistent and comprehensive studies that can compare the multiple environmental and socioeconomic impacts of the dominant modes of Jatropha production: smallholder-based projects and large plantations (von Maltitz and Setzkorn 2013, Gasparatos et al. 2015). To date the only empirical syntheses/ comparative studies of the impact of Jatropha projects in southern Africa have either collated findings from empirical studies that were conducted at different times or used different methodologies (van Eijck et al. 2014a, Romijn et al. 2014).

Furthermore, most impact studies have not gone beyond the early establishment phase of Jatropha projects (Schoneveld et al. 2011, German et al. 2011). Thus, given that most Jatropha projects collapsed before reaching maturity, we lack a proper understanding of their impacts once fully operational.

Our aim is to provide a comparative analysis of the environmental and socioeconomic impacts that manifest in two maturing operational Jatropha projects in southern Africa that represent both a large plantation and smallholder-based model:

${ }^{1}$ CSIR, South Africa, ${ }^{2}$ Nelson Mandela Metropolitan University, South Africa, ${ }^{3}$ Integrated Research System for Sustainability Science (IR3S), University of Tokyo, Tokyo, Japan, ${ }^{4}$ Sustainability Research Unit, Nelson Mandela Metropolitan University, South Africa, ${ }^{5}$ Independent development practitioner, Malawi, ${ }^{6}$ Department of Zoology, University of Oxford, UK, ${ }^{7}$ Royal Botanical Gardens Kew, UK 
Table 1. Ecosystem services impact mechanisms of Jatropha cultivation in sub-Saharan Africa. Adapted from Gasparatos et al. 2012, 2015.

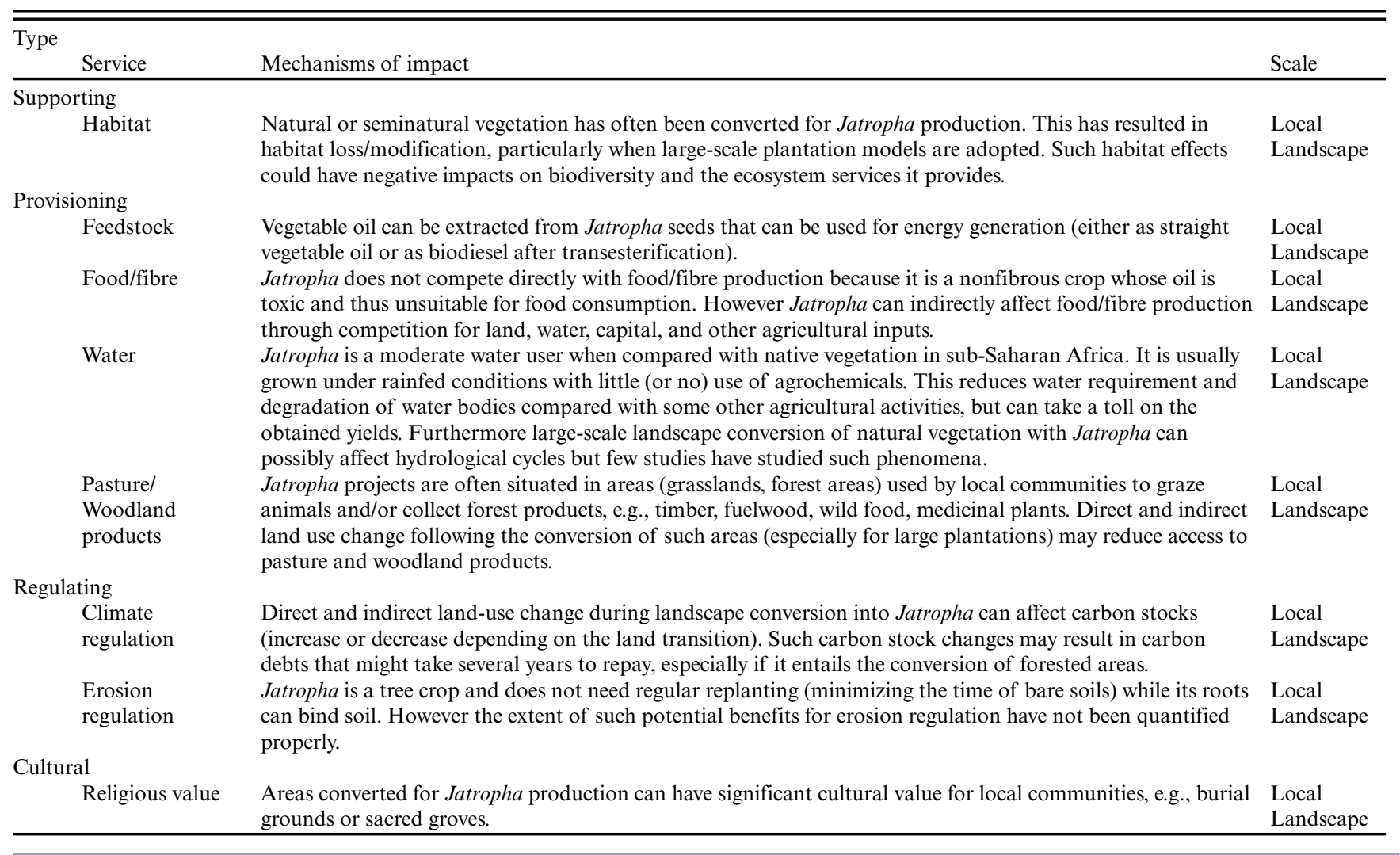

- a large-scale estate-based block plantation, Niqel Lda (Niqel), Mozambique;

- a smallholder-based project predominantly employing hedgerow cultivation, BioEnergy Resources Ltd (BERL), Malawi

We adopt the ecosystem services (ES) approach to identify how land conversion for Jatropha production has affected the provision of ecosystem services, i.e., the benefits that humans obtain from nature, and the ripple effects for the well-being and poverty alleviation of local communities (MA 2005, TEEB 2010, Fisher et al. 2014, Díaz et al. 2015). The ES approach is ideal for studying biofuel projects because it links the social and ecological dimensions of biofuel production (Gasparatos et al. 2011, 2013b). Several studies have used the ES approach to synthesize knowledge about the impacts of biofuels (Gasparatos et al. 2011, Holland et al. 2015, Jolly et al. 2015), including Jatropha in subSaharan Africa (Gasparatos et al. 2012; Tables 1 and 2).

The ES approach has also been used to quantify the impacts of biofuel projects (Bennett and Isaacs 2014, Meyer et al. 2015) but to our best knowledge it has not been used for empirical studies in the African context. However, through its systems-oriented perspective (Díaz et al. 2015), the ES approach can offer a more systematic overview of biofuel sustainability when compared to indicator-based assessments (Meyer et al. 2015) that is currently missing from biofuel studies at the African context (Gasparatos et al. 2015). In this respect our study offers a complementary (but not mutually exclusive) lens to understand biofuel impacts compared with other indicator-based studies in Africa (van Eijck et al. 2014a, Romijn et al. 2014).

For the purpose of this paper we focus on changes in provisioning services that manifest at the local level. This is because of the following:

- The most profound impacts of biofuel projects in Africa on human well-being manifest at the local level (Gasparatos et al. 2012, 2015; Tables 1 and 2). This is largely due to the fact that biofuel projects are often located in poor rural settings where local communities rely heavily on provisioning ecosystem services (mostly associated with subsistence agriculture and woodland products) for their livelihoods;

- The drivers of biofuel expansion in sub-Saharan Africa are mainly associated with rural development and energy security, rather than climate change mitigation (von Maltitz and Stafford 2011, Gasparatos et al. 2013a). This is particularly true for BERL/Niqel that do not aim to export biofuel to overseas markets, but to use it domestically (von Maltitz et al. 2014, Table 3). 
Table 2. Human well-being impacts of Jatropha cultivation in sub-Saharan Africa ${ }^{\dagger}$. Adapted from Gasparatos et al. $2012,2015$.

\begin{tabular}{ll}
\hline \hline Constituent & Mechanisms of impact \\
\hline Employment & $\begin{array}{l}\text { Jatropha plantations can provide rural employment in areas of little other formal employment opportunities. However, such } \\
\text { employment benefits can be limited because of the low employment density of Jatropha plantations. Temporary employment } \\
\text { is also prevalent during some times of the year, e.g., harvesting periods. }\end{array}$
\end{tabular}

Income Plantation workers: for agricultural tasks the income received from Jatropha plantations is often little, and it is usually close to national minimum salaries. However, the stability of this income is often highly valued. Higher paid/skilled jobs (usually nonagricultural tasks) are often offered to members outside the local communities. Smallholders/outgrowers: Jatropha is a low-value crop and therefore the prices received by selling Jatropha seeds are usually very low. However, in some cases the harvest of Jatropha coincides with periods of the crop calendar year when food crop supplies run low. In such cases Jatropha-related income can be a useful buffer for livelihood shocks.

Energy Local level: Jatropha oil has sometimes been used to fuel power generators for rural electrification. Such projects can security potentially boost rural energy security, but many of them in Africa have collapsed without achieving the expected benefits. National level: Jatropha-based transport fuels could in theory reduce the import of expensive foreign fuels offering significant foreign savings (especially for landlocked countries). In reality with the collapse of most Jatropha projects in subSaharan Africa very little (if any at all) Jatropha oil is used for transport. Other alternative uses such as power generation for telecommunication towers are explored by some of the remaining operational Jatropha projects.

Food Local level: Effect on local food security can be variable and dependent on project characteristics. Land-use change during security Jatropha conversion can divert land/labor/capital/agricultural inputs from food production (reduced food availability). Jatropha income can be used to buy food (increased access to food).

National/international: Theoretically as more land is converted into Jatropha, less land will be available for food production. Modeling exercises at the national level have found varying effects of Jatropha expansion on food security (food availability effects). Biofuel-driven food price increases are also possible but there is inconclusive evidence about such effects in Africa (access to food effects).

Local

Several documented cases exist of local communities losing access to communal lands from Jatropha projects or not being

Land tenure and social conflicts compensated appropriately (or at all). On several occasions local communities were disregarded in the land acquisition procedures between Jatropha companies and national governments/local traditional authorities. This has resulted in local agitations that in some cases were a major driver for the collapse of some Jatropha projects.

\footnotetext{
${ }^{\dagger}$ Jatropha project collapse could have very profound negative effects on most aspects of human well-being directly (e.g., loss of employment, income) or indirectly (e.g., decrease of food/energy security). The actual nature and scale of effects can depend on a number of project-specific factors.
}

\section{METHODS}

\section{Study sites}

Niqel Mozambique

Niqel is a commercial block plantation established in 2007 (Table 3). Planting started in 2009, with the first seeds harvested in 2012-2013. As a greenfield project, Niqel plantation undertook extensive clearing of existing woodland and the voluntary relocation of some local community members and their fields. Households that chose not to relocate were functionally surrounded by the plantation.

The Environmental Impact Assessment (EIA) found that while settlement and farm density varied across the Niqel area, on average only $11.5 \%$ ( $<1 \%$ in some areas) of the land was cultivated (CES 2009). The predominant livelihood activity in the area was by far small-scale subsistence agriculture. Family farms, referred to locally as a mashambas, employ slash-and-burn rotational farming, where trees are cut down and burnt to increase soil fertility. Based on EIA findings, Niqel plantation was limited to areas that had neither high population density, nor high forest cover.

\section{BERL Malawi}

BERL is a private company that incentivized individual smallholders in Malawi to grow Jatropha as hedges demarcating the boundaries of their farms (though some farmers have opted to develop small block plantations within their farms). BERL was also registered under the Voluntary Carbon Standard v3 to gain carbon credits from carbon sequestration in the woody biomass of Jatropha.

BERL assisted 230,000 smallholders in 10 regions of Malawi to uptake Jatropha using a network of extension officers and seed buyers (Table 3 ). These promotion, extension and buying services were discontinued in 2014, with BERL eventually focusing solely on Jatropha seed purchase and oil extraction.

The farmers in the study villages (Machinga district) started growing Jatropha in 2008-2009, with their first commercial harvest coinciding with our site visits in March 2013. At that point the surveyed farmers were harvesting their second or third reaping of their first harvest season.

\section{Data collection and analysis}

We conducted back-to-back fieldworks on both sites in March 2013 with follow-up visits in 2014. At both sites we employed a two-stage approach for data collection. Initially we visited the study sites with knowledgeable local informants and conducted focus group discussions with local communities and open-ended semistructured interviews with key informants, e.g., Niqel/BERL project managers, local chiefs. This information was used to refine 
Table 3. Key characteristics of the Niqel and BERL Jatropha projects†.

\begin{tabular}{|c|c|c|}
\hline & Bio Energy Resources Ltd. (BERL) Malawi & Niqel Lda (Niqel) Mozambique \\
\hline Project type & $\begin{array}{l}\text { Smallholders-based Jatropha production in hedgerows on } \\
\text { private farms. } \\
\text { BERL purchases seeds from smallholders, and extracts and sells } \\
\text { the oil. }\end{array}$ & $\begin{array}{l}\text { Large-scale Jatropha production in commercial block plantation. } \\
\text { Plantation owned and managed by Niqel using paid labor. }\end{array}$ \\
\hline Project history & $\begin{array}{l}\text { Planting started in } 2008-2009 \\
\text { First harvest in December } 2012 \\
\text { Stockpiling Jatropha oil until legislation allows its sale for } \\
\text { transport fuel (approved in mid-2014). }\end{array}$ & $\begin{array}{l}\text { Planting started in } 2009 \\
\text { Harvesting from } 2013 \\
\text { Stockpiling seeds until a press is installed (expected mid-2015) }\end{array}$ \\
\hline Location & $\begin{array}{l}\text { Smallholders located in } 10 \text { districts of Malawi. } \\
\text { Study villages (Chimwaza, Msala, Joho, Lipende) located in } \\
\text { Machinga district. }\end{array}$ & $\begin{array}{l}\text { Plantation located between Grudja and Mutindiri villages, Buzi } \\
\text { district, Sofala province }\end{array}$ \\
\hline Household size & $\begin{array}{l}5.6 \text { persons/household }(2.1 \mathrm{SD}) \text { with } 2.8(1.6 \mathrm{SD}) \text { children below } \\
\text { the age of } 15\end{array}$ & $\begin{array}{l}7.5 \text { persons/household }(3.5 \mathrm{SD}) \text { with } 3.8(2.5 \mathrm{SD}) \text { children below } \\
\text { the age of } 15 \text {. }\end{array}$ \\
\hline Population density and & Machinga district: 127 people $/ \mathrm{km}^{2}$ & Buzi district: 25.5 people $/ \mathrm{km}^{2}$ \\
\hline land availability & $\begin{array}{l}\text { Farms typically less than } 2 \text { ha, though there is unquantified } \\
\text { common areas }\end{array}$ & $\sim 27$ ha of land available per household \\
\hline Altitude & $650-800 \mathrm{~m}$ above mean sea level & $\sim 100 \mathrm{~m}$ above mean sea level \\
\hline $\begin{array}{l}\text { Rainfall } \\
\text { Climate and mean } \\
\text { monthly temperature }\end{array}$ & $\begin{array}{l}\text { Summer rainfall } 767-1025 \mathrm{~mm} \text {. } \\
\text { Tropical } \\
\text { Liwonde, } 18-26^{\circ} \mathrm{C}\end{array}$ & $\begin{array}{l}\text { Summer rainfall } 1100-1500 \mathrm{~mm} \\
\text { Tropical } \\
\text { Beira } 24-31^{\circ} \mathrm{C} \\
\text { Chimoio } 18-24^{\circ} \mathrm{C}\end{array}$ \\
\hline Topography & $\begin{array}{l}\text { Hilly } \\
\text { Loamy sands or sandy loams, with clay loams in lowlands }\end{array}$ & $\begin{array}{l}\text { Appears flat, but undulating with well-developed catena } \\
\text { sequences. } \\
\text { Sands at top of catena and heavy clays at the bottom }\end{array}$ \\
\hline Vegetation & $\begin{array}{l}\text { Miombo vegetation } \\
\text { Heavily deforested }\end{array}$ & $\begin{array}{l}\text { Miombo woodland with patches of acacia woodland, } \\
\text { hydromorphic grasslands, and Colophospermum Mopani groves } \\
\text { (near rivers). }\end{array}$ \\
\hline $\begin{array}{l}\text { Feedstock production } \\
\text { model }\end{array}$ & $\begin{array}{l}\text { BERL recommended model is a } 400-600 \text {-tree hedge } \\
\text { surrounding the border of the family farm. } 1 \text {-m tree } \\
\text { espacement. }\end{array}$ & $\begin{array}{l}\text { Block plantation of } 6500 \text { ha at its maximum extent } \\
1250 \text { trees per ha in } 4 \times 2-m \text { espacement. }\end{array}$ \\
\hline $\begin{array}{l}\text { Seed yields expectations } \\
\text { in business plan }\end{array}$ & $\begin{array}{l}0.80 \mathrm{~kg} / \text { Jatropha tree } \\
\text { A } 400-600 \text { tree hedgerow should provide a family farm with } \sim \\
\text { USD } 100 / \text { year. }\end{array}$ & $\begin{array}{l}3 \text { t/ha to achieve profitability as stated in the economic analysis } \\
\text { of the EIA }\end{array}$ \\
\hline End use & $\begin{array}{l}\text { Jatropha oil to be used domestically. } \\
\text { Expected to be directly blended into diesel fuel (mainly for } \\
\text { transport) up to a maximum of } 9 \% \text { (B9 blend) }\end{array}$ & $\begin{array}{l}\text { Jatropha oil to be shipped to Maputo for transportation fuel. } \\
\text { Potential to be used to power diesel generators in } \\
\text { telecommunication towers }\end{array}$ \\
\hline
\end{tabular}

a household survey that included qualitative and quantitative questions.

We subsequently conducted household surveys in areas surrounding Niqel plantation (Mozambique) and five villages in Machinga district (Malawi) where farmers had adopted Jatropha cultivation after being introduced to it by BERL (referred to as BERL smallholders from this point forward). The household survey was designed to provide a rapid assessment of the effect of land conversion to Jatropha on the provision of ecosystem services, and the effects of involvement in Jatropha (as workers, smallholders) on human well-being and poverty alleviation. The main focus was on changes in provisioning services (biofuel feedstock vs. food crops, fodder, and woodland products; Tables 4 and 5) because these tend to have the most immediate and direct impacts on local human well-being and poverty alleviation at the local scale.

The household survey contained questions about household demographics, agricultural activities, crop yields, access to ecosystem services, energy use patterns, food security, poverty (all at the household level), and general qualitative questions about the perceptions of growing Jatropha (BERL smallholders) or working in a Jatropha plantation (Niqel plantation). Where possible, the same questions were used at both sites to allow for some comparisons. However, given the differences between households employed in a plantation, with those undertaking smallholder Jatropha production, required some customization between the two surveys. For example, questions about agricultural production were more detailed for the BERL smallholders survey because there was competition for farmland between Jatropha and other crops; this was not the case for the Niqel plantation because there is no Jatropha production by smallholders/outgrowers on individual farms. To identify temporal changes, respondents were asked to compare their current situation (2013) with 5 years (2008) and 10 years (2003) before. Given that both Jatropha projects were initiated around 2008 (Table 3 ), the 5-year recall question coincides with the early stages of operation for both BERL/Niqel.

To capture changes in the provision of ecosystem services we compared the ecosystem services provided before and after the 
Table 4. Indicators and data sources for studied ecosystem services.

\begin{tabular}{|c|c|c|c|c|c|}
\hline \multirow[t]{2}{*}{ Variable } & \multirow[t]{2}{*}{ Indicator } & \multirow[t]{2}{*}{ Type } & \multicolumn{2}{|c|}{ Data sources } & \multirow[t]{2}{*}{ Comparative basis } \\
\hline & & & Niqel & BERL & \\
\hline \multicolumn{6}{|l|}{ Feedstock } \\
\hline \multirow[t]{2}{*}{$\begin{array}{l}\text { Jatropha } \\
\text { production }\end{array}$} & Jatropha produced last season (for Niqel; ton/yr) & Quantitative & $\begin{array}{l}\text { Company } \\
\text { records }\end{array}$ & Quantitative & $\begin{array}{l}\text { State before/after } \\
\text { introduction of } \\
\text { Jatropha }\end{array}$ \\
\hline & Jatropha produced last season (for BERL; Kg/yr) & Quantitative & NA & Quantitative & $\begin{array}{l}\text { State before/after } \\
\text { introduction of } \\
\text { Jatropha }\end{array}$ \\
\hline \multicolumn{6}{|l|}{ Food crops } \\
\hline \multirow[t]{2}{*}{$\begin{array}{l}\text { Food crop } \\
\text { production }\end{array}$} & $\begin{array}{l}\text { Type of crop produced over time (last season, } 5 \text { and } 10 \\
\text { years ago) }\end{array}$ & Qualitative & $\begin{array}{l}\text { Household } \\
\text { survey }\end{array}$ & Qualitative & $\begin{array}{l}\text { State before/after } \\
\text { introduction of } \\
\text { Jatropha }\end{array}$ \\
\hline & Food crops produced last season $(\mathrm{Kg} / \mathrm{yr})^{\dagger}$ & Quantitative & & Quantitative & \\
\hline \multicolumn{6}{|l|}{ Livestock } \\
\hline $\begin{array}{l}\text { Livestock } \\
\text { ownership }\end{array}$ & $\begin{array}{l}\text { Number of animals over time (last season, } 5 \text { and } 10 \\
\text { years ago) }\end{array}$ & Quantitative & $\begin{array}{l}\text { Household } \\
\text { survey }\end{array}$ & Quantitative & $\begin{array}{l}\text { State before/after } \\
\text { introduction of } \\
\text { Jatropha }\end{array}$ \\
\hline \multicolumn{6}{|c|}{ Pasture/ woodland products } \\
\hline \multirow[t]{2}{*}{$\begin{array}{l}\text { Use of pasture/ } \\
\text { woodland } \\
\text { products }\end{array}$} & $\begin{array}{l}\text { Household use of woodland products and pasture over } \\
\text { time (last season, } 5 \text { and } 10 \text { years ago) }\end{array}$ & Qualitative & $\begin{array}{l}\text { Household } \\
\text { survey }\end{array}$ & Qualitative & $\begin{array}{l}\text { State before/after } \\
\text { introduction of } \\
\text { Jatropha }\end{array}$ \\
\hline & Perception of reliance on pasture/woodland products & Qualitative & & Qualitative & \\
\hline \multicolumn{6}{|c|}{ 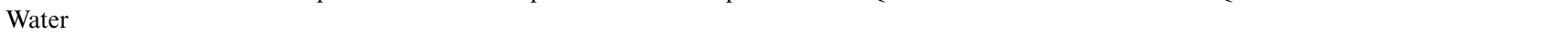 } \\
\hline $\begin{array}{l}\text { Water } \\
\text { availability }\end{array}$ & $\begin{array}{l}\text { Perception of change of water availability since } \\
\text { beginning of Jatropha production }\end{array}$ & Qualitative & $\begin{array}{l}\text { Household } \\
\text { survey }\end{array}$ & Qualitative & $\begin{array}{l}\text { State before/after } \\
\text { introduction of } \\
\text { Jatropha }\end{array}$ \\
\hline Water quality & $\begin{array}{l}\text { Perception of change of water quality since beginning } \\
\text { of Jatropha production }\end{array}$ & Qualitative & & Qualitative & \\
\hline \multicolumn{6}{|l|}{ Cultural services } \\
\hline $\begin{array}{l}\text { Use of land for } \\
\text { recreation and } \\
\text { religious } \\
\text { activities }\end{array}$ & Perception of loss of cultural services & Qualitative & $\begin{array}{l}\text { Focus } \\
\text { groups, } \\
\text { expert } \\
\text { interviews }\end{array}$ & Qualitative & $\begin{array}{l}\text { State before/after } \\
\text { introduction of } \\
\text { Jatropha }\end{array}$ \\
\hline
\end{tabular}

conversion of forest/agricultural land to Jatropha (Table 4). This is between the start of Niqel/BERL activities (2008) and our survey (2013; Table 3). To capture insights related to human wellbeing and poverty alleviation we compared groups with different involvement in Jatropha activities, i.e., intervention groups (estate workers, smallholders) and nonintervention groups (control groups; Table 5). Where possible, the comparisons took place on two different levels:

- between different groups for 2013: to understand the relative effect of involvement in Jatropha activities;

- for the same group (intervention group) over time (2008-2013): to understand the absolute effects of the intervention.

Collectively these effects on land modification and community members represented what we call changes due to the Niqel and BERL models. Given the unique site characteristics we minimized direct comparisons between the BERL and Niqel models unless well justified by the results.

We should note that poverty and food security are multidimensional concepts, which cannot be captured in their entirety through simple indicators (Alkire and Foster 2011,
Carletto et al. 2013). For poverty, apart from standardized information on income and employment, we used a variation of the multidimensional poverty index developed by the Oxford Poverty and Human Development Initiative (OPHI; Alkire and Santos 2010). For this we considered the (i) accumulation of material assets, and access to (ii) water, (iii) sanitation, (iv) schooling, (v) housing. We excluded the OPHI health and child mortality indicators because the time frame from the start of the Jatropha projects to the initiation of the study was considered too short for any measurable effects to have occurred. For food security the household survey captured two key aspects; (i) changes in food availability due to changes in farming practices following involvement in Jatropha-related activities, e.g., diversion of land/labor/agricultural inputs, and (ii) changes in access to food due to the income received from involvement in Jatropha-related activities.

We conducted 81 household surveys around Niqel plantation: 35 to Niqel employees (intervention group), and 46 to households with no links to Niqel (control group). At the BERL smallholder villages we administered 98 questionnaires: 55 to Jatropha growers (intervention group) and 43 to nongrowers (control group). All interviews were confidential and anonymous, but with the respondents' permission, we took video recordings of some 
Table 5. Indicators and data sources for studied components of human well-being and multidimensional poverty.

\begin{tabular}{|c|c|c|c|c|c|}
\hline \multirow[t]{2}{*}{ Variable } & \multirow[t]{2}{*}{ Indicator } & \multirow[t]{2}{*}{ Type } & \multicolumn{2}{|c|}{ Data sources } & \multirow[t]{2}{*}{ Comparative basis } \\
\hline & & & Niqel & BERL & \\
\hline \multicolumn{6}{|l|}{ Employment } \\
\hline \multirow{2}{*}{$\begin{array}{l}\text { Involvement in } \\
\text { remunerative } \\
\text { Jatropha } \\
\text { activities }\end{array}$} & $\begin{array}{l}\text { Number of plantation jobs in community (permanent } \\
\text { and temporary; for Niqel) }\end{array}$ & Quantitative & $\begin{array}{l}\text { Company } \\
\text { records }\end{array}$ & NA & $\begin{array}{l}\text { Intervention and } \\
\text { control households }\end{array}$ \\
\hline & $\begin{array}{l}\text { Number of growers per study village (for BERL } \\
\text { smallholders) }\end{array}$ & Quantitative & NA & $\begin{array}{l}\text { Household } \\
\text { survey, expert } \\
\text { interviews }\end{array}$ & \\
\hline \multicolumn{6}{|l|}{ Income } \\
\hline \multirow[t]{2}{*}{$\begin{array}{l}\text { Jatropha-related } \\
\text { income }\end{array}$} & $\begin{array}{l}\text { Income from plantation work or selling Jatropha seeds } \\
\text { (local currency/yr) }\end{array}$ & Quantitative & $\begin{array}{l}\text { Household } \\
\text { survey, } \\
\text { expert } \\
\text { interviews }\end{array}$ & $\begin{array}{l}\text { Household } \\
\text { survey, expert } \\
\text { interviews }\end{array}$ & $\begin{array}{l}\text { Intervention and } \\
\text { control households }\end{array}$ \\
\hline & $\begin{array}{l}\text { Fraction of Jatropha-related income to overall } \\
\text { household income (in } \% \text { ) }\end{array}$ & Quantitative & $\begin{array}{l}\text { Household } \\
\text { survey }\end{array}$ & $\begin{array}{l}\text { Household } \\
\text { survey }\end{array}$ & \\
\hline \multicolumn{6}{|l|}{ Food security } \\
\hline \multirow[t]{5}{*}{$\begin{array}{l}\text { Availability of } \\
\text { food }\end{array}$} & $\begin{array}{l}\text { Agricultural land area change over time (last season, } 5 \\
\text { and } 10 \text { years ago; in ha) }\end{array}$ & Quantitative & $\begin{array}{l}\text { Household } \\
\text { survey }\end{array}$ & $\begin{array}{l}\text { Household } \\
\text { survey }\end{array}$ & $\begin{array}{l}\text { Intervention and } \\
\text { control households }\end{array}$ \\
\hline & $\begin{array}{l}\text { Crop displacement to grow Jatropha (only for BERL } \\
\text { smallholders) }\end{array}$ & Qualitative & NA & & \\
\hline & $\begin{array}{l}\text { Time investment to grow Jatropha (only for BERL } \\
\text { smallholders) }\end{array}$ & Quantitative & & & \\
\hline & $\begin{array}{l}\text { Perception of farm production since started to grow } \\
\text { Jatropha (only for BERL smallholders) }\end{array}$ & Qualitative & & & \\
\hline & $\begin{array}{l}\text { Effect of Jatropha on crop yields (only for BERL } \\
\text { smallholders) }\end{array}$ & Qualitative & & & \\
\hline $\begin{array}{c}\text { Perception of } \\
\text { huger }\end{array}$ & $\begin{array}{l}\text { Periods of food scarcity (last season, } 5 \text { and } 10 \text { years ago; } \\
\text { months/yr) }\end{array}$ & Quantitative & $\begin{array}{l}\text { Household } \\
\text { survey }\end{array}$ & $\begin{array}{l}\text { Household } \\
\text { survey }\end{array}$ & \\
\hline \multicolumn{6}{|l|}{ Energy security } \\
\hline \multirow[t]{2}{*}{ Fuel use } & Type of fuel used for cooking and lighting & Qualitative & $\begin{array}{l}\text { Household } \\
\text { survey }\end{array}$ & $\begin{array}{l}\text { Household } \\
\text { survey }\end{array}$ & $\begin{array}{l}\text { Intervention and } \\
\text { control households }\end{array}$ \\
\hline & Dependence on woodland products for cooking fuel & Qualitative & & & \\
\hline \multicolumn{6}{|l|}{ Multidimensional poverty } \\
\hline \multirow[t]{2}{*}{ Education } & Completion of 5-year schooling within household & Quantitative & $\begin{array}{l}\text { Household } \\
\text { survey }\end{array}$ & $\begin{array}{l}\text { Household } \\
\text { survey }\end{array}$ & $\begin{array}{l}\text { Intervention and } \\
\text { control households }\end{array}$ \\
\hline & School attendance of primary school-aged children & Quantitative & & & \\
\hline Access to toilet & $\begin{array}{l}\text { Cement flooring in household } \\
\text { Access to toilet not shared with other household }\end{array}$ & $\begin{array}{l}\text { Qualitative } \\
\text { Qualitative }\end{array}$ & & & \\
\hline Access to water & $\begin{array}{l}\text { Access to an improved source of drinking water less } \\
\text { than } 30 \text { min walking }\end{array}$ & Qualitative & & & \\
\hline $\begin{array}{l}\text { Household } \\
\text { assets }\end{array}$ & $\begin{array}{l}\text { Ownership of different asset classes over time (last } \\
\text { season, } 5 \text { and } 10 \text { years ago) }\end{array}$ & Quantitative & & & \\
\hline
\end{tabular}

individual interviews and focus group discussions to develop a short video highlighting key findings of the study (See video at https://vimeo.com/67382494).

For the BERL-smallholder study we further developed a simple farm-economic model to calculate economic returns to land. This model was based on data reported by farmers, i.e., economic returns of land under food crops compared with Jatropha. Gross margin was calculated as the total value of all crops produced minus the costs of fertilizer inputs. We assumed that the first 50 $\mathrm{kg}$ of fertilizer was obtained at nationally subsidized rates (MKW $800 / 50 \mathrm{~kg}$ ), with the rest obtained at market rates (MKW 16000/50 $\mathrm{kg}$ if purchased from local shops). Crops for domestic consumption were valued at their local market value as provided by key informants. Gross margins were divided by the land area of non-Jatropha crops to obtain the returns to land. For Jatropha the value of Jatropha sales was divided by the area under Jatropha to obtain Jatropha return to land. Area under Jatropha was calculated by measuring the length and width of 10 Jatropha hedges, and dividing the area by the number of Jatropha trees to get mean area per tree $\left(\mathrm{m}^{2} /\right.$ tree $)$. Because there is no smallholder Jatropha production around Niqel plantation, this was not done for this study site.

\section{RESULTS: ECOSYSTEM SERVICES, HUMAN WELL- BEING, AND POVERTY ALLEVIATION}

\section{Ecosystem services}

Feedstock

Feedstock for fuel is the main ecosystem service obtained after the conversion of forest/agricultural land to Jatropha (Table 1). Yield data provided by Niqel plantation was $0.4 \mathrm{t} / \mathrm{ha}$ in husks (approximately $0.24 \mathrm{t} / \mathrm{ha}$ once dehusked) for their two-year trees (Niqel project management staff, personal communication). Based on the $2 \times 4$ spacing adopted, this corresponded to a yield of 0.32 
$\mathrm{Kg} /$ tree $(0.19 \mathrm{~kg} /$ tree dehusked). BERL smallholders reported on average less than $0.1 \mathrm{~kg} /$ tree of dehusked seeds (wet mass as sold; Fig. 1). At the time of the survey seed yields were only $13 \%$ of BERL smallholders' and Niqel plantation's long term expectations (Table 3). However that was to be expected since it was their first harvests

Fig. 1. Mean Jatropha seed yields per tree (air-dried as sold) reported by BERL smallholders (based on the first season harvest until the time of the survey in March 2013).

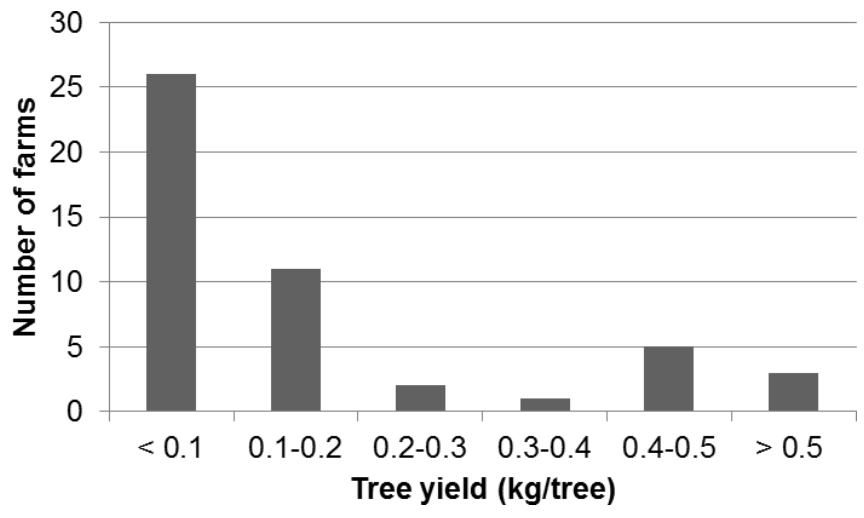

Growing Jatropha can divert resources, e.g., land/labor/water/ capital/other agricultural inputs, from food crop production (Table 1), possibly having a significant effect on food availability (Table 2, see Food Security). However, land availability around the Niqel plantation is not a limiting factor; because of low population densities, displaced households were assisted in creating new fields. Field sizes seemed to be largely limited by the available household labor resources rather than any factor caused by the expansion of the plantation. For example a few households had established relatively large farms (up to 14 ha) that produced substantial excess crops for sale. Self-reported farm sizes do not show any significant difference between 2008 and 2013 (Table 6).

Table 6. Changes in agricultural land between 2008 and 2013.

\begin{tabular}{|c|c|c|c|}
\hline & \multirow[t]{2}{*}{$\mathrm{N}$} & \multicolumn{2}{|c|}{ Land (ha) } \\
\hline & & 2013 & 2008 \\
\hline \multicolumn{4}{|l|}{ BERL (Malawi) } \\
\hline Jatropha growers & 55 & 1.8 & 1.6 \\
\hline Nongrowers & 43 & 1.4 & 1.2 \\
\hline Total & 98 & & \\
\hline \multicolumn{4}{|l|}{ Niqel (Mozambique) } \\
\hline Nonemployees & 46 & 4.8 & 4.8 \\
\hline $\begin{array}{l}\text { Permanent } \\
\text { employees }\end{array}$ & 22 & 3.3 & 3.7 \\
\hline Seasonal employees & 13 & 2.4 & 1.9 \\
\hline Total & 81 & & \\
\hline
\end{tabular}

By contrast BERL smallholders had to divert both their land and labor from other agricultural activities into Jatropha production. In BERL smallholder villages, farms with set boundaries are allocated to individual farmers. Farm sizes remained largely unchanged between 2008 and 2013 as identified by respondents (Table 6). These farms are smaller and more permanent when compared with farms around the Niqel plantation.
BERL smallholders mostly grew Jatropha as hedgerows on the border of their farms, though some grew hedges or block plantations within the farms. In both models there was the possibility that Jatropha trees displace or interfere with other crops (see Discussion). BERL project management staff pointed out that farm boundaries are likely to be previously uncultivated land (BERL project management staff, personal communication). However, our field measurements suggest that a 500-tree Jatropha hedge, as recommended by BERL, would reduce the potential crop area by 0.1 ha, which corresponded to $7 \%$ of an average family farm in the studied villages. In reality, because farmers typically grew fewer than the recommended number of Jatropha trees, on average only $4.3 \%$ of farms were occupied by Jatropha, however with substantial variation between farms.

The above findings suggest that land availability has not affected food production potential negatively at Niqel and only marginally for BERL smallholders. This finding is corroborated by a remote sensing study conducted by Romeu-Dalmau et al. (2016) for the Niqel area and BERL smallholder villages adopting similar techniques as the study villages in the current paper.

Fodder, livestock, and woodland products

BERL smallholders produced Jatropha on existing agricultural land because of the hedgerow model adopted. As a result direct woodland conversion due to Jatropha expansion was neither evident nor identified through focus group discussions. Niqel plantation was mostly established in woodlands that were cleared to make way for the plantation. These woodlands were previously used by the community for multiple uses such as grazing animals and sourcing woodland products as identified through focus group discussions and expert interviews. Apart from direct woodland clearing from the Niqel plantation, there was also indirect land use change (ILUC) from displaced farmers clearing new farms in the surrounding woodlands. This can potentially affect other provisioning ecosystem services such as fodder (and ultimately livestock), fuelwood, and nontimber forest products (Tables 1 and 2).

Although the Niqel plantation clearly reduced the land available for grazing, it did not appear to affect livestock rearing because it was not an important part of local livelihoods anyway. The area is not particularly suitable for cattle because of tsetse fly infestation, while there were, on average, only 1.4 goats/ household, despite each household having access on average to $\sim 25$ ha of land. For BERL smallholders, because Jatropha is planted predominantly on field boundaries, there was no evidence that it replaced fodder crops. As such it has limited impact on fodder and livestock.

It should be mentioned that communities in both areas depend significantly on woodland products such as fuelwood, charcoal, timber, and wild food among others (Table 7). Households in the BERL smallholder villages reported an increasing reliance on woodland products over the past 10 years. Households around the Niqel plantation reported a decreasing reliance on woodland products. Although the conversion of woodland for Jatropha production has most likely decreased the availability of woodland products, none of the respondents around Niqel plantation raised concerns about declining access to these woodland products. This echoes the Niqel EIA finding that although woodland products were important for local communities, respondents seemed to have little concern that the plantation would compromise their 
access because they considered the remaining forest to be sufficient to meet their needs (CES 2009). However this does not preclude declining access to woodland products in the future.

Table 7. Woodland product use ( $\%$ of households).

\begin{tabular}{lccccccc}
\hline \hline & \multicolumn{3}{c}{ BERL areas, Malawi } & & \multicolumn{3}{c}{$\begin{array}{c}\text { Niqel area, } \\
\text { Mozambique }\end{array}$} \\
\cline { 2 - 4 } \cline { 6 - 8 } $\begin{array}{l}\text { Woodland } \\
\text { product }\end{array}$ & 2013 & 2008 & 2003 & & 2013 & 2008 & 2003 \\
\hline Fuelwood & 100 & 99 & 94 & & 98 & 94 & 93 \\
Charcoal & 14 & 13 & 10 & & 7 & 2 & 2 \\
Wild fruit & 55 & 46 & 11 & & 29 & 55 & 57 \\
Fish & 0 & 0 & 0 & & 35 & 43 & 40 \\
Honey & 28 & 18 & 4 & & 25 & 34 & 36 \\
Wild animals & 6 & 4 & 3 & & NA & NA & NA \\
Mushrooms & 53 & 50 & 6 & & 26 & 35 & 36 \\
\hline
\end{tabular}

\section{Other ecosystem services}

Respondents at both the BERL smallholder villages and around Niqel plantation did not perceive Jatropha to be reducing the quantity and quality of their local freshwater resources. In both areas Jatropha was produced under rainfed conditions with minimal input of agrochemicals. This is consistent with studies in South Africa that demonstrated that Jatropha plantations are unlikely to use more water than natural vegetation (Gush 2008, Everson et al. 2013; Table 1). Key informants around Niqel plantation indicated that access to freshwater might have increased. This was due to borrow pits dug during road maintenance filling with water. In addition, Niqel built a small dam to provide a local community with better access water. Some BERL smallholders suggested that Jatropha trees might in fact help stream-flow by reducing erosion (Table 1) but this could not be validated by field experiments.

In the Niqel plantation model there is a potentially important decline of climate regulation services because our expert interviews and focus groups indicate the large-scale conversion of dense Miombo woodland to Jatropha plantation. Such conversion can result in significant carbon debts as studies in other parts of southern Africa have suggested (Achten and Verchot 2011, Romijn 2011, Vang Rassmunen et al. 2012, von Maltitz et al. 2012). For BERL smallholders, larger carbon quantities might be sequestered through the introduction of trees into agricultural fields traditionally dominated by maize. In hedge cultivations settings in Malawi Jatropha might actually provide climate regulation services, but this requires further investigation (e.g., Makungwa et al. 2013). These insights from expert interviews and focus groups are corroborated from a recent study of carbon stock changes in the Niqel plantation and some BERL villages (RomeuDalmau et al. 2016).

Finally, focus groups and key informant interviews around Niqel plantation showed that the woodlands provided cultural ecosystem services, particularly associated with burial grounds and religious activities. Although Niqel used local headmen to identify culturally significant features such as graveyards and sacred trees to ensure that they are not destroyed, community members mentioned that there had been isolated instances where the Niqel land-clearing activities during the establishment of the plantation accidentally destroyed graves. This was a source of discontent within the community. By contrast, interviews and focus group discussions with BERL smallholders identified no impacts on cultural ecosystem services as a consequence of Jatropha planting.

\section{Human well-being}

\section{Employment and income generation}

Involvement in Jatropha activities should, theoretically, have had a positive effect on human well-being through income and employment opportunities (Table 2). In turn, these higher income opportunities should lead to household asset accumulation.

Niqel plantation directly employed $\sim 230$ full-time and 85-150 seasonal workers, offering benefits to approximately $9 \%$ of the local community households. Wages for permanent unskilled workers, though low, matched or exceeded the Mozambique agricultural sector's minimum wage of MZN 2300/month ( US $\$ 77 /$ month). Based on farmers' self-reported crop sales in the household survey, one month's wages were about the same as the median farm annual income from selling crops. For seasonal workers, the salary is based on the volume of seeds picked at approximately US\$0.05/kg (unshelled). Assuming Niqel plantation pickers pick at the same rate as the BERL smallholders, and that husks are $30 \%$ of seed mass, then pickers could earn US\$1.14/8-hour working day. To put this into perspective, in 2009 women in the Niqel plantation area were being paid US\$0.03 to weed a $30-\mathrm{m}$ row of maize, an agricultural activity that is likely to be both more energy- and time-consuming than seed picking (CES 2009).

For BERL smallholders, the financial returns from Jatropha at the time of survey were modest. Actual Jatropha seed sales ranged between US\$0 to 27 per household. Estimates provided by farmers suggest that it took on average 23.5 minutes to pick and 38 minutes to dehusk one kilogram of seeds. This kilogram of seed would sell for US\$0.27 (i.e., US\$1.36/8-hour day). Many farmers complained that the selling price was too low compared to the effort and resources they have invested (see abovementioned video). It should be noted that BERL did not purchase more Jatropha seeds from the study villages in 2013, suggesting that the above figures are a good representation of the Jatropha income received in 2012-2013 from the surveyed households (BERL project management staff, personal communication).

Actual economic returns from BERL smallholders' Jatropha sales were only weakly correlated with the area under Jatropha (Fig. 2). Eight out of 55 Jatropha growing households reported disproportionally high economic returns, all from small areas of Jatropha. By contrast a number of farmers with larger block plantations or extensive hedgerows reported proportionally low returns (Fig. 3).

When considering the total net-value of crops produced by BERL smallholders, including food crops for domestic consumption, Jatropha farms exhibited a mean net-crop-value of US\$149/farm, while non-Jatropha farms achieved US\$116/farm (though this difference was not significant). However, Jatropha growers had on average significantly larger farms ( 1.83 vs $1.42 \mathrm{ha}, \mathrm{p}=0.012$ tail t-test), producing $92.43 \mathrm{US} \$ /$ ha compared to nongrowers 121.24 US $\$$ ha. The larger farm size of Jatropha growing households also meant that they were more likely to receive income from selling food crop surplus (US\$16.76/farm vs US\$-4.89/farm, $p=0.03$, 2-tail t-test). Because most of the food 
crops are consumed by the household (and not sold), it is not uncommon that money received from crop sales did not cover fertilizer input costs, hence the negative value.

Fig. 2. Income of BERL farmers from Jatropha sales (based on the first season harvest until the time of the survey in March 2013).

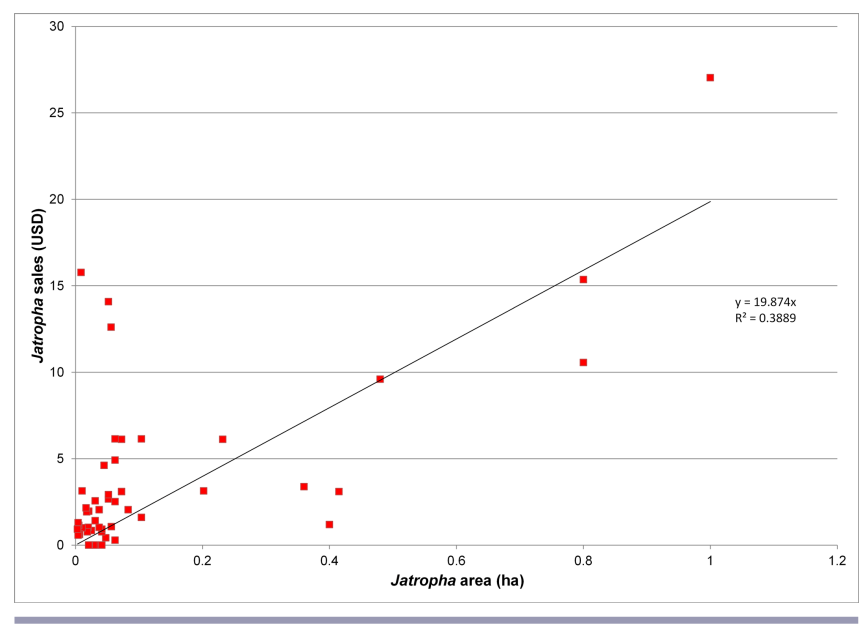

Fig. 3. Income per unit area under Jatropha for BERL farmers planting Jatropha in hedgerows and block plantations (based on the first season harvest until the time of the survey in March 2013).

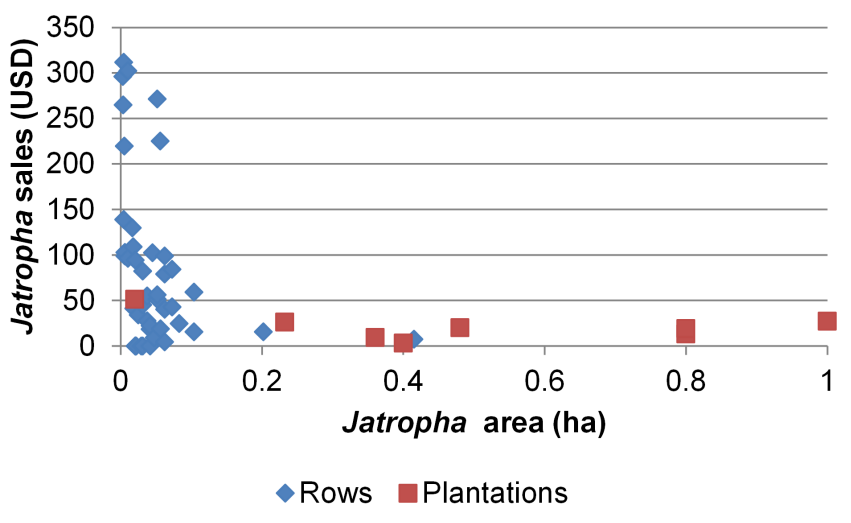

For most BERL smallholders, the economic returns per unit land under Jatropha were lower than the mean return to land from the combination of the farmers' other crops (gross margin per unit land; Fig. 4). There were a few exceptions with higher returns from Jatropha per unit land, but all these were linked with farms dedicating small areas to Jatropha (Fig. 3).

We modeled potential return to land if farmers were to achieve higher yields in the future, which is justified considering that the Jatropha trees offered their first yields during our field visits. For the modeling we kept all non-Jatropha crop data constant and assumed Jatropha yields of $0.4 \mathrm{~kg} /$ tree, which is approximately the yields experienced by the few higher yielding farms (Fig. 1), but still only $50 \%$ of what BERL is predicting (Table 3 ). Our results suggest that if yields of $0.4 \mathrm{~kg} /$ tree are realized from mature trees, and assuming Jatropha trees do not affect the productivity of other crops as they mature, then in almost all cases Jatropha returns exceed the proportional returns expected from the land area occupied if food crops are grown.

Fig. 4. Jatropha contributions to total farm income versus area under Jatropha comparing actual tree yields with modeled data for an average Jatropha yield of $0.4 \mathrm{~kg}$ seeds/tree.

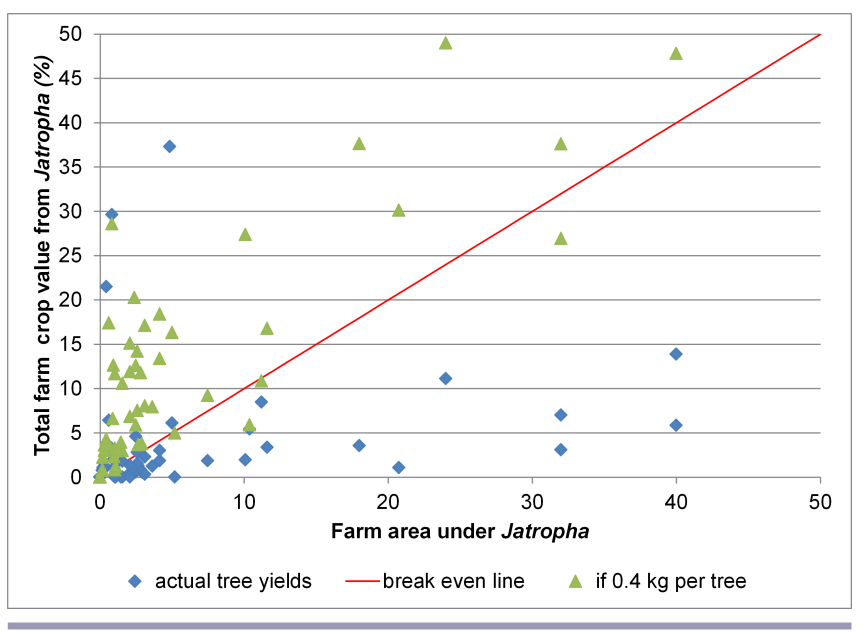

Food security

Permanent laborers for Niqel plantation reported a slight decrease in farm sizes (from 3.7 to 3.3 ha) between 2013 and 2008, i.e., since before the plantation was fully established (Table 6). Casual laborers working for Niqel plantation reported a slight increase in mean farm size (from 1.9 to $2.4 \mathrm{ha}$ ), while local farmers not working for Niqel plantation rated their current mean land as unchanged for the same period (at $4.8 \mathrm{ha}$ ). When asked if they had enough land, $82 \%$ of permanent laborers, $100 \%$ of seasonal laborers, and $98 \%$ of nonlaborers said they had enough land.

Although the establishment of the Niqel plantation did not significantly reduce farm sizes or number of farms (though some farms were relocated), it diverted the household labor of its workers away from subsistence farming. To reduce this effect Niqel plantation aimed to employ only one individual per household. However, respondents employed by Niqel plantation indicated that if they were short of labor for cropping their own farms, then they hired the required labor (this was observed during the follow-up visit in November 2014). We could not accurately quantify the yield differences between workers and nonworkers in the Niqel plantation because households had difficulty reporting absolute yields and therefore we do not report it in this section; however, respondents in both focus group interview and responses in questionnaires did not raise reduced food production as an issue.

Niqel plantation managers hypothesized that the road infrastructure developed by Niqel, and the injection of cash into the region, potentially enhanced agricultural production (Niqel project management staff, personal communication), though no specific evidence was found to support this. Jatropha-related income, and most importantly the financial stability it brought to plantation workers, may have resulted in greater purchasing 
Table 8. Households in Malawi reporting hunger each month ( $\%$ of households).

\begin{tabular}{|c|c|c|c|c|c|c|c|c|c|c|c|c|}
\hline & Jul & Aug & Sep & Oct & Nov & Dec & Jan & $\mathrm{Feb}$ & Mar & Apr & May & Jun \\
\hline Grow Jatropha & 2 & 7 & 15 & 25 & 42 & 56 & 82 & 73 & 11 & 0 & 0 & 2 \\
\hline Not grow Jatropha & 15 & 23 & 28 & 40 & 50 & 63 & 80 & 80 & 25 & 13 & 3 & 15 \\
\hline Total & 7 & 14 & 20 & 32 & 45 & 59 & 81 & 76 & 17 & 5 & 1 & 7 \\
\hline
\end{tabular}

power of involved households, allowing them to buy additional food. Focus group discussions and interviews with Niqel plantation workers suggested that the income received, allowed them to have better access to food and acted as a safety net for households during times of need, e.g., after drought. Specifically, they said (see above-mentioned video), "People used to die because of the hunger. Now, with the company it is better for them," and "People used to sell their maize to be able to buy things for the house and they sometimes would have no food, now the maize is just for food, the money comes from the company and so now things are different."

Farms sizes in BERL villages did not change significantly between 2008 and 2013, (Table 6). However Jatropha growing households had statistically significant larger farm sizes compared to control households ( 1.83 vs. 1.43 ha, $\mathrm{p}=0.01)$. Based on the harvest data of BERL smallholders, mean maize, soybean, and pigeon pea yields were slightly higher for Jatropha growing households, though this difference was not statistically significant and is most likely attributable to their statistically significant larger farms. Potato, cassava, and groundnuts harvests were slightly, and nonsignificantly, lower for Jatropha growers than nongrowers. When asked for their perceptions of the impact of Jatropha on other crops, 13 of the 55 interviewed Jatropha growers perceived that growing Jatropha reduced adjacent crop yields, whereas 3 farmers indicated that it increased crop yields. Finally, of the 14 surveyed households that grew tobacco, 10 also grew Jatropha, and all owned farms larger than 1.5 ha. This suggests that households with larger farms are more likely to be able to afford to diversify into cash crops.

Though the cash benefits from selling Jatropha for the BERL smallholders were minimal (and possibly not stable), it was perceived positively when considered against the high prevalence of hunger in the area (Table 8). Farmers stated that if cash was needed, they could use this income for other household needs rather than selling their food crops (see above-mentioned video).

\section{Energy security}

Feedstock from both Niqel and BERL was not used by local communities adjacent to the Jatropha production areas to meet their energy requirements. In both areas fuelwood, and to a lesser extent charcoal, constituted almost $100 \%$ of household cooking fuels (Table 9). For BERL smallholders and surrounding communities, little or no impact from Jatropha expansion on access to fuelwood is expected because no deforestation takes place on account of Jatropha. Around Niqel plantation there is currently more fuelwood than needed to meet local energy needs, so forest conversion to Jatropha is unlikely to impact household access to fuelwood in the foreseeable future.
Table 9. Fuels used for cooking ( $\%$ of households $)^{\dagger}$.

\begin{tabular}{lcc}
\hline \hline Fuel & BERL (Malawi) & Niqel (Mozambique) \\
\hline Wood & 100 & 98 \\
Charcoal & 14 & 7 \\
Paraffin & 0 & 0 \\
Electricity & 0 & 0 \\
Gas & 0 & 0 \\
Other & 1 & 0 \\
\hline Results for BERL Jatropha growers and nongrowers (Malawi); and \\
employed and nonemployed in Niqel plantation (Mozambique) were \\
very similar. This table includes fuel use for all households in each \\
location.
\end{tabular}

No households in either area mentioned using Jatropha fruits or wood as fuels for cooking (Jatropha wood is a very poor fuel) or for lighting (to use the oil would have required local pressing). Paraffin was a major source of lighting in the past, but the introduction of cheap LED torches has radically changed light sources over the past few years, and is now used in most households (Table 10). Jatropha-related income could in theory, improve households' access to LED lights and batteries. Interestingly, BERL's Jatropha oil is purchased by fishermen communities in Nhotakota region for use in lamps for night fishing (BERL project management staff, personal communication). Although this can have some (potentially positive) effects on human well-being, further research would be required to ascertain the actual magnitude.

Table 10. Fuels used for lighting ( $\%$ of households $)^{\dagger}$.

\begin{tabular}{lccccccc}
\hline & \multicolumn{3}{c}{ BERL (Malawi) } & & \multicolumn{3}{c}{ Niqel (Mozambique) } \\
\cline { 2 - 3 } Fuel & 2013 & 2008 & 2003 & & 2013 & 2008 & 2003 \\
\hline Candles & 2 & 4 & 1 & & 16 & 23 & 17 \\
Torch & 76 & 15 & 4 & & 78 & 46 & 31 \\
Paraffin & 31 & 89 & 98 & & 22 & 44 & 47 \\
Electricity & 0 & 0 & 0 & & 1 & 1 & 0 \\
Gas & 0 & 0 & 0 & & 0 & 0 & 0 \\
Nothing & 4 & 5 & 2 & & 0 & 0 & 0 \\
Other (e.g., & 3 & 3 & 5 & & 9 & 21 & 25 \\
maize husks) & & & & & &
\end{tabular}

"Results for BERL Jatropha growers and nongrowers (Malawi); and employed and nonemployed in Niqel plantation (Mozambique) were very similar. This table includes fuel use for all households in each location.

Because the feedstock produced by Niqel and BERL will be used in other areas of the country from where it is produced (Table 3), a critical consideration of the potential national energy security benefits of Jatropha-based fuels will be the yields realized and the 
Table 11. Farm size and value of farm produce, comparing growers and non-Jatropha growers in Malawi and workers on the Jatropha plantation in Mozambique with nonworkers.

\begin{tabular}{|c|c|c|c|c|}
\hline & $\begin{array}{l}\text { Farm size } \\
(\text { ha } \pm \text { SD) }\end{array}$ & $\begin{array}{c}\text { Cash received (US\$) } \\
\text { Median (min, max) }\end{array}$ & $\begin{array}{c}\text { Net income } \\
\text { (US\$) }^{\ddagger} \\
\text { Median (min, max) }\end{array}$ & $\begin{array}{c}\text { Total net-value of crop (US\$) } \\
\text { Median (min, max) }\end{array}$ \\
\hline \multicolumn{5}{|l|}{$\overline{\text { BERL (Malawi) }}$} \\
\hline Grow Jatropha & $1.8 \pm 0.55$ & $20(0,379)$ & $14(-235,336)$ & $111(-82,759)$ \\
\hline Not grow Jatropha & $1.4 \pm 0.75$ & $12(0,31)$ & $0(-191,112)$ & $65(-53,913)$ \\
\hline All Farmers & $1.7 \pm 0.67$ & $20(0,379)$ & $14(-235,336)$ & $111(-82,913)$ \\
\hline \multicolumn{5}{|l|}{ Niqel (Mozambique) } \\
\hline Not employed & $4.8 \pm 3.39$ & $67(0,1665)$ & 67 & NA \\
\hline Employed & $3.3 \pm 1.46$ & $37(0,2331)$ & 37 & NA \\
\hline Casual labor & $2.4 \pm 1.59$ & $25(0,599)$ & 25 & NA \\
\hline All farmers & $4.0 \pm 2.87$ & $50(0,2331)$ & 50 & NA \\
\hline
\end{tabular}

overall energy return on investment (Gasparatos et al.2011,2012). Niqel plantation is in the process of establishing a pressing facility on site, expected to be operational in the second half of 2015. If Niqel plantation is able to harvest $3 \mathrm{t} / \mathrm{ha}$ of seeds from $6500 \mathrm{ha}$, then it could produce $\sim 6500$ t/year Jatropha oil (based on $30 \%$ oil content), which would be equivalent to $1.3 \%$ of Mozambique's estimated diesel demand (509,000 tonnes in 2009; CES 2009). This means that Niqel plantation could potentially supply almost half of Mozambique's targeted 3\% biodiesel blend. However, this is contingent on the realized future yields.

BERL, through its pressing plant in Lilongwe, intends to directly blend filtered Jatropha oil with diesel, thus reducing national reliance on the currently $100 \%$ imported diesel fuel. This was to be initially piloted with commercial vehicle fleets, with the prospect of extended to all diesel as Jatropha oil supply increases (BERL project management staff, personal communication). During our visit, production was at a pilot stage, and it was not until late 2014 that government permission was obtained to commence blending (BERL project management staff, personal communication). Malawi uses $\sim 141,000$ tonnes diesel/year (IEA 2010 ), so the proposed $9 \%$ blend would require $\sim 12,700$ tonnes of Jatropha oil. BERL estimated that in 20 years the demand would reach 27,000 tonnes (BERL project management staff, personal communication). To meet BERL's estimates of farmers receiving US\$100 from 400-600 trees, this would require each tree to produce $0.92-1.3 \mathrm{~kg}$ seed/year. If this yield can be realized when the trees mature, then BERL's 27,000 tonne biofuel supply could be achieved from $\sim 200,000$ growers.

\section{Poverty alleviation}

Before dissecting the actual effects of Jatropha on poverty alleviation, it is important to put into perspective the poverty patterns in the two study sites. Although both study sites were remote and deeply poor, the multidimensional poverty indicators suggest marked differences between poverty profiles in the two areas (Fig. 5). BERL smallholder villages in Malawi tended to have better access to schooling, permanent housing, and water than the local community around Niqel plantation in Mozambique (Fig. 5). Almost all surveyed households in BERL smallholder villages had invested in permanent housing structures, whereas communities around Niqel plantation largely resided in traditional mud-and-thatched structures. On the other hand, respondents around Niqel plantation had higher cash incomes from farming and accumulated more (relatively cheap) assets such as radios, bicycles, and mobile phones.

Fig. 5. Multidimensional poverty indicators for farmers in Malawi and Mozambique (\% of households).

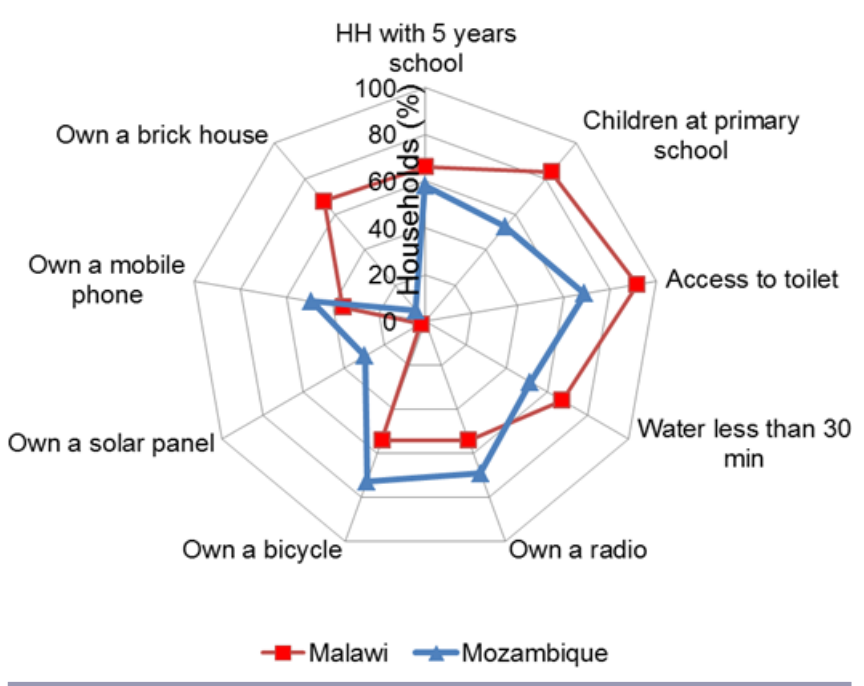

Comparing income from agriculture, farmers around Niqel plantation (for both intervention and control groups) were generating more cash income from cropping than their BERL smallholder counterparts (Table 11). These greater agricultural returns can be attributed to the larger farm sizes, the higher maize price in Mozambique, the lack of expenditure on fertilizer (none of the respondents used chemical fertilizer around Niqel), and the fact that new fields can be readily opened in a slash-and-burn manner in response to declining soil fertility. However, the differences between intervention and control groups in the two sites are less clear, i.e., Jatropha growers and nongrowers in BERL smallholder villages, and between workers and nonworkers at Niqel plantation (Table 12). 
Table 12. Multidimensional poverty indicators for each study group (\%).

\begin{tabular}{|c|c|c|c|c|c|c|c|c|c|c|c|c|c|c|c|c|c|c|c|}
\hline & \multirow[t]{2}{*}{$\mathrm{N}$} & \multicolumn{3}{|c|}{$\begin{array}{c}\text { At least } 5 \text { years of } \\
\text { schooling }\end{array}$} & \multicolumn{3}{|c|}{ No schooling } & \multicolumn{3}{|c|}{ Access to toilet } & \multicolumn{3}{|c|}{ Access to water } & \multicolumn{3}{|c|}{ Own Radio } & \multicolumn{3}{|c|}{ Own TV } \\
\hline & & 2013 & 2008 & 2003 & 2013 & 2008 & 2003 & 2013 & 2008 & 2003 & 2013 & 2008 & 2003 & 2013 & 2008 & 2003 & 2013 & 2008 & 2003 \\
\hline \multicolumn{20}{|c|}{ BERL (Malawi) } \\
\hline $\begin{array}{l}\text { Jatropha } \\
\text { growers }\end{array}$ & 55 & 67 & 60 & 53 & 84 & 89 & 96 & 96 & 100 & 100 & 65 & 58 & 78 & 56 & 76 & 76 & 0 & 0 & 0 \\
\hline Nongrowers & 43 & 65 & 47 & 44 & 84 & 88 & 79 & 86 & 95 & 93 & 70 & 58 & 74 & 51 & 65 & 51 & 12 & 9 & 9 \\
\hline Total & 98 & 66 & 54 & 49 & 84 & 89 & 89 & 92 & 98 & 97 & 67 & 58 & 77 & 54 & 71 & 65 & 5 & 4 & 4 \\
\hline \multicolumn{20}{|c|}{ Niqel (Mozambique) } \\
\hline Nonemployees & 46 & 57 & 33 & 26 & 54 & 78 & 78 & 74 & 65 & 67 & 41 & 33 & 30 & 80 & 85 & 83 & 2 & 2 & 0 \\
\hline $\begin{array}{l}\text { Permanent } \\
\text { employees }\end{array}$ & 22 & 59 & 45 & 27 & 59 & 77 & 68 & 55 & 68 & 64 & 73 & 59 & 59 & 59 & 77 & 82 & 0 & 0 & 0 \\
\hline $\begin{array}{l}\text { Seasonal } \\
\text { employees }\end{array}$ & 13 & 62 & 38 & 38 & 38 & 69 & 77 & 77 & 46 & 38 & 54 & 38 & 31 & 46 & 62 & 54 & 8 & 0 & 0 \\
\hline Total & 81 & 58 & 37 & 28 & 53 & 77 & 75 & 69 & 63 & 62 & 52 & 41 & 38 & 69 & 79 & 78 & 2 & 1 & 0 \\
\hline \multirow[t]{2}{*}{ (cont'd) } & $\mathrm{N}$ & \multicolumn{3}{|c|}{ Own bicycle } & \multicolumn{3}{|c|}{ Own solar panel } & \multicolumn{3}{|c|}{ Own brick house } & \multicolumn{3}{|c|}{ Own mobile phone } & \multicolumn{3}{|c|}{ Own motorbike } & \multicolumn{3}{|c|}{ Own car } \\
\hline & & 2013 & 2008 & 2003 & 2013 & 2008 & 2003 & 2013 & 2008 & 2003 & 2013 & 2008 & 2003 & 2013 & 2008 & 2003 & 2013 & 2008 & 2003 \\
\hline \multicolumn{20}{|c|}{ BERL (Malawi) } \\
\hline $\begin{array}{l}\text { Jatropha } \\
\text { growers }\end{array}$ & 55 & 60 & 58 & 53 & 2 & 0 & 0 & 73 & 73 & 65 & 36 & 0 & 0 & 0 & 0 & 0 & 0 & 0 & 0 \\
\hline Nongrowers & 43 & 47 & 44 & 35 & 2 & 0 & 0 & 60 & 53 & 49 & 35 & 0 & 0 & 0 & 0 & 0 & 0 & 0 & 0 \\
\hline Total & 98 & 54 & 52 & 45 & 2 & 0 & 0 & 67 & 64 & 58 & 36 & 0 & 0 & 0 & 0 & 0 & 0 & 0 & 0 \\
\hline \multicolumn{20}{|c|}{ Niqel (Mozambique) } \\
\hline Nonemployees & 46 & 83 & 78 & 76 & 39 & 22 & 7 & 11 & 9 & 48 & 48 & 28 & 11 & 9 & 2 & 2 & 4 & 2 & 2 \\
\hline $\begin{array}{l}\text { Permanent } \\
\text { employees }\end{array}$ & 22 & 64 & 77 & 73 & 27 & 27 & 14 & 0 & 0 & 50 & 50 & 41 & 18 & 9 & 9 & 5 & 0 & 0 & 0 \\
\hline $\begin{array}{l}\text { Seasonal } \\
\text { employees }\end{array}$ & 13 & 54 & 62 & 62 & 0 & 8 & 0 & 0 & 0 & 54 & 54 & 38 & 15 & 0 & 0 & 0 & 0 & 0 & 0 \\
\hline Total & 81 & 73 & 75 & 73 & 30 & 21 & 7 & 6 & 5 & 49 & 33 & 33 & 14 & 7 & 4 & 2 & 2 & 1 & 1 \\
\hline
\end{tabular}

For the Niqel plantation we expected that Jatropha workers would have more purchased assets as an indication of the income received. The data suggest the opposite because a larger proportion of farmers that are not working for Niqel plantation owned more assets than laborers, with seasonal laborers being particularly impoverished (Tables 11 and 12). It is probable that only the poorest in the community are willing to take the relatively low paid seasonal jobs such as Jatropha picking for Niqel plantation. Reasons as to why the permanent laborers at Niqel plantation are not investing in material goods is not clear, though it is possible that our choice of assets may be inappropriate and they might be investing in other purchases such as clothing, education, or food given their, on average, smaller fields (Table 11). This is partly supported by their farm income (Table 11) and multidimensional poverty indicators such as education (Table 12). However, permanent staff for Niqel plantation tends to have far higher crop incomes than casual laborers. This supports the idea that it is only the truly poor who are attracted to the salaries offered for casual labor, which may be an important financial safety net for them.

\section{DISCUSSION}

Our study identifies changes in the provision of ecosystem services following the conversion of forest (Niqel plantation) and agricultural (BERL smallholders) land (Fig. 6). In more detail, results suggest that while feedstock production increased in both sites, food, feed, and livestock ecosystem services remained largely unaffected (Fig. 6).

Land is abundant in the area around Niqel plantation, and displaced households could readily receive new land (predominately miombo woodland) to convert for crop cultivation. However, extensive areas of miombo woodland were cleared to establish the Niqel Jatropha plantation for biofuel feedstock production. This resulted in decreased ecosystem services provided by the woodland including a range of woodland products (e.g., wood fuel, construction materials, fruits), cultural services, and carbon sequestration. Although these effects were not quantified, focus groups discussions, interviews, and subsequent studies (Romeu-Dalmau et al. 2016) all suggest that negative impacts on ecosystem services were a consequence of the plantation establishment.

Indirect land use change (ILUC) due to farmer displacement from the plantation may have enhanced these impacts. We expect the following ILUC effects around Niqel plantation: (i) new farms being opened by displaced farmers; (ii) existing farms expanding because the improved road infrastructure can allow easier selling of crop surplus; (iii) new farms opened from in-migrants drawn 
in the area because of new income opportunities and better infrastructure (Niqel project management staff, personal communication). Such ILUC effects can result in carbon stock losses (Achten and Verchot 2011) and changes in hydrological cycles (Lawrence and Vandecar 2015) especially if natural vegetation is converted. Quantifying ILUC effects can be very complex (Finkbeiner 2014), but is a major gap in the current biofuel literature in Africa (Gasparatos et al. 2015). Though not investigated specifically in this study, direct and indirect largescale woodland conversion at Niqel plantation could also have had substantive biodiversity impacts (von Maltitz et al. 2010, Blanchard et al. 2011, 2014, Immerzeel et al. 2014).

Fig. 6. Changes in the provision of ecosystem services after land transformation in Niqel and BERL areas.

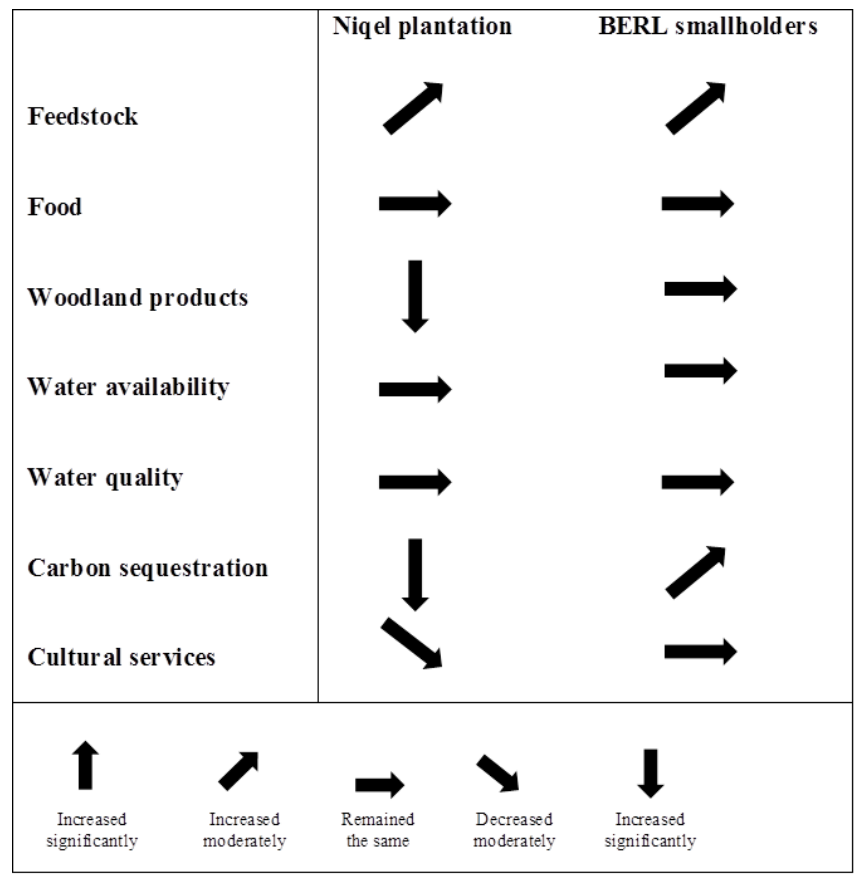

Given the small, direct land-use change associated with growing Jatropha in hedges, we believe that ILUC effects for BERL smallholders will be minimal. The current evidence does not support a reduction in food crops as a consequence of Jatropha, so this should not be a driver of agricultural expansion. However see our potential concerns below.

Labor displacement from subsistence agriculture to Jatropharelated activities was not found to decrease local food crop production in either area. For BERL smallholders, picking and dehusking Jatropha were time-consuming activities conducted predominantly by women and children. These activities were probably secondary, and most likely limited to times of available labor. Those BERL smallholders that chose to convert large proportions of their farms to Jatropha, typically reported disproportionately low Jatropha sales. This may indicate that they preferentially placed labor on what they perceived as higher value crops. On the other hand Niqel plantation workers (permanent and seasonal) benefited from paid labor in an area with limited job opportunities. However, seed picking in particular was poorly rewarded and was mainly associated with seasonal employment.
In both sites at the time of fieldwork Jatropha activities were relatively recent, so it was not possible to distinguish strong poverty alleviation effects, i.e., large improvement of poverty indicators for groups involved in Jatropha activities (Table 12) because of the received income. However, our results can identify those demographic groups, most likely to be involved in Jatropharelated activities. In BERL smallholder villages, Jatropha was largely taken up by households that tended to have more land, that were slightly better off in terms of asset accumulation, and historically had higher levels of education (Table 12). This finding is consistent with studies in Malawi and Zambia (Mponela et al. 2011, Kuntashula et al. 2014). On the other hand for Niqel plantation the income and multidimensional poverty indicators seem to suggest that it is only the poorer members of the community that are attracted to employment (whether permanent or temporary).

Clearly Jatropha is unlikely to provide economic returns at the level that many investors had originally anticipated (Borman et al. 2013, Gasparatos et al. 2015, von Maltitz et al. 2014, van Eijk $2014 a, b)$. However, if yields continue to improve as trees mature, then Jatropha could provide a meaningful contribution to the overall income of BERL smallholders. In addition, there is evidence that picking rate should increase as yields improve (Borman et al. 2013), and this would improve daily profit to both BERL smallholders and casual laborers at Niqel plantation. If Niqel becomes financially viable in the long-term, then it could inject much-needed cash into a deeply poor rural area with few other income options.

Jatropha yields remain a key unknown and this, more than anything else, is likely to determine the long-term viability of both projects. Full-year data from mature Jatropha trees is needed before it is possible to clarify whether Jatropha is actually a good economic use of land in both areas. Improvements in tree yields through breeding could improve both production models, however, many BERL smallholders and a large proportion of Niqel plantation land are locked into trees of unproven quality. To replace these is expensive, and would result in further delays to achieve the yields necessary for economic viability.

An interesting finding was that some BERL smallholders report disproportionately high Jatropha sales from small land areas. We speculate four plausible reasons, but further research would be needed to verify them: (i) Jatropha hedges can be more productive than block plantations because they can access fertilizer, moisture, and other resources from surrounding crops; (ii) households need to invest considerable amounts of time for tree management and seed picking, which is more likely to lead to high yields from individual trees when small areas are involved; (iii) some households collect seeds from trees outside their family farm; (iv) some trees and/or locations offer superior yields because of soil properties, local climate, and/or germplasm.

Finally, the potential impact of Jatropha hedges on the yields of adjacent crops for BERL smallholder farms is a major gap in the literature. In addition to the land displaced by the actual tree, there is the potential for yield suppression (or enhancement) of adjacent crops because of changes in micro-climate, and competition for light, water, and/or nutrients. This impact may be exacerbated during drought years, when water competition could decrease the overall yields of crops close to Jatropha hedges. On the other hand, Jatropha income in drought years may be an 
important safety net allowing farmers to purchase food. Currently there is no available data on which to predict the nature of these interactions and their overall impact on livelihoods.

\section{CONCLUSIONS}

Despite the collapse of many Jatropha projects in southern Africa, our observations from the Niqel plantation and BERL smallholder villages are cautiously optimistic. At the stage of the fieldwork, there was little evidence of any impact from changes in ecosystem services being devastatingly negative. Yet it is also evident that the positive effects are still small.

Current results suggest that there can be overall positive human well-being benefits in both projects in terms of employment and income, provided that they become viable in the long-term, which is not yet proven. Both projects are still vulnerable to low seed yields, lack of markets, and barriers posed by national governments.

If minimum yields of $0.4 \mathrm{~kg} /$ tree for BERL smallholders or 3 tonnes/ha for Niqel plantation are attained in the future, then national energy security benefits are to be expected, with minimal impacts on local food security. This is, however, partly a result of the unique properties and location of each project and cannot be extrapolated to other projects with different situations.

Finally, although the generated income is relatively small in both projects, it must be considered in the context of the extreme poverty currently experienced in both study areas. This income may well prove to be important for the food security of involved households, again with site-specific effects. Different socioeconomic groups will reap different benefits from involvement in Jatropha activities. In the BERL smallholder project it appears that it is only the relatively better-off households (especially those with larger land holdings) that become involved in Jatropha production. By contrast it seems to be the poorer community members that find attractive the low salary of permanent and seasonal labor opportunities in the Niqel plantation. Overall it is likely to be the BERL smallholders can enjoy more widespread poverty alleviation benefits, though this is contingent on sufficiently high Jatropha yields being realized.

Responses to this article can be read online at: http://www.ecologyandsociety.org/issues/responses. $\mathrm{php} / 8554$

\section{Acknowledgments:}

The authors acknowledge funding from the UK NERC-ESRCDFID Ecosystem Services for Poverty Alleviation Programme (ESPA; Grant: EIRG-2011-180).

\section{LITERATURE CITED}

Achten, W. M. J., and L. V. Verchot. 2011. Implications of biodiesel-induced land-use changes for $\mathrm{CO}_{2}$ emissions: case studies in Tropical America, Africa, and Southeast Asia. Ecology and Society 16(4):14. http://dx.doi.org/10.5751/ES-04403-160414
Alkire, S., and J. Foster. 2011. Understandings and misunderstandings of multidimensional poverty measurement. Journal of Economic Inequality 9:289-314. http://dx.doi. org/10.1007/s10888-011-9181-4

Alkire, S., and M. E. Santos. 2010. Multidimensional poverty index. The Oxford Poverty and Human Development Initiative (OPHI), Oxford, UK.

Bennett, A. B., and R. Isaacs. 2014. Landscape composition influences pollinators and pollination services in perennial biofuel plantings. Agriculture, Ecosystems and Environment 193:1-8. http://dx.doi.org/10.1016/j.agee.2014.04.016

Blanchard, R., P. J. O'Farrell, and D. M. Richardson. 2014. Anticipating potential biodiversity conflicts for future biofuel crops in South Africa: incorporating spatial filters with species distribution models. Global Change Biology: Bioenergy 7 (2):273-287. http://dx.doi.org/10.1111/gcbb.12129

Blanchard, R., D. M. Richardson, P. J. O'Farrell, and G. P. von Maltitz. 2011. Biofuels and biodiversity in South Africa. South African Journal of Science 107(5/6):19-26. http://dx.doi. org/10.4102/sajs.v107i5/6.186

Borman, G. D., G. P. von Maltitz, S. Tiwari, and M. C. Scholes. 2013. Modelling the economic returns to labour for Jatropha cultivation in southern Africa and India at different local fuel prices. Biomass and Bioenergy 59:70-83. http://dx.doi. org/10.1016/j.biombioe.2012.06.020

Carletto, C., A. Zezza, and R. Banerjee. 2013. Towards better measurement of household food security: harmonizing indicators and the role of household surveys. Global Food Security 2:30-40. http://dx.doi.org/10.1016/j.gfs.2012.11.006

Coastal and Environmental Services (CES). 2009. Dutch Jatropha consortium environmental and social impact assessment (ESIA): report for Phase 1. Coastal and Environmental Services, Grahamstown, South Africa.

Díaz, S., S. Demissew, J. Carabias, C. Joly, M. Lonsdale, N. Ash, A. Larigauderie, J. R. Adhikari, S. Arico, A. Báldi, et al. 2015. The IPBES conceptual framework: connecting nature and people. Current Opinion in Environmental Sustainability 14:1-16. http:// dx.doi.org/10.1016/j.cosust.2014.11.002

Everson, C. S., M. G. Mengistu, and M. B. Gush. 2013. A field assessment of the agronomic performance and water use of Jatropha curcas in South Africa. Biomass and Bioenergy 59:59-69. http://dx.doi.org/10.1016/j.biombioe.2012.03.013

Finkbeiner, M. 2014. Indirect land use change: help beyond the hype? Biomass and Bioenergy 62:218-221. http://dx.doi. org/10.1016/j.biombioe.2014.01.024

Fisher, J. A., G. Patenaude, K. Giri, K. Lewis, P. Meir, P. Pinho, M. D. A. Rounsevell, and M. Williams. 2014. Understanding the relationships between ecosystem services and poverty alleviation: a conceptual framework. Ecosystem Services 7:34-45. http://dx. doi.org/10.1016/i.ecoser.2013.08.002

Gasparatos, A., L. Y. Lee, G. P. von Maltitz, M. Mathai, J. A. Puppim de Oliveira, F. X. Johnson, and K. J. Willis. $2013 a$. Catalysing biofuel sustainability: international and national policy interventions. Environmental Policy and Law 43:216-221. 
Gasparatos, A., L. Y. Lee, G. P. von Maltitz, M. Mathai, J. A. Puppim de Oliveira, and K. J. Willis. 2012. Biofuels in Africa: impacts on ecosystem services, biodiversity and human wellbeing. United Nations University Institute for the Advanced Study of Sustainability, Yokohama, Japan.

Gasparatos, A., M. Lehtonen, and P. Stromberg. 2013b. Do we need a unified appraisal framework to synthesize biofuel impacts? Biomass and Bioenergy 50:75-80. http://dx.doi.org/10.1016/j. biombioe.2012.09.052

Gasparatos, A., P. Stromberg, and K. Takeuchi. 2011. Biofuels, ecosystem services and human wellbeing: putting biofuels in the ecosystem services narrative. Agriculture, Ecosystems and Environment 142:111-128. http://dx.doi.org/10.1016/j.agee.2011.04.020

Gasparatos, A., G. P. von Maltitz, F. X. Johnson, L. Y. Lee, M. Mathai, J. A. Puppim de Oliveira, and K. J. Willis. 2015. Biofuels in Africa: drivers, impacts and priority policy areas. Renewable and Sustainable Energy Reviews 45:879-901. http://dx.doi. org/10.1016/j.rser.2015.02.006

German, L., G. C. Schoneveld, and D. Gumbo. 2011. The local social and environmental impacts of smallholder-based biofuel investments in Zambia. Ecology and Society 16(4):12. http://dx. doi.org/10.5751/es-04280-160412

Global Exchange for Social Investment (GEXSI). 2008. Global market study on Jatropha. Final report. Global Exchange for Social Investment, Berlin, Germany.

Gush, M. B. 2008. Measurement of water use by Jatropha curcas L using the heat-pulse velocity technique. Water South Africa $34: 5$.

Henning, R. K. 2009. The Jatropha system: an integrated approach of rural development. Bagani, Weissenberg, Germany.

Holland, R. A., F. Eigenbrod, A. Muggeridge, G. Brown, D. Clarke, and G. Taylor. 2015. A synthesis of the ecosystem services impact of second generation bioenergy crop production. Renewable and Sustainable Energy Reviews 46:30-40. http://dx. doi.org/10.1016/j.rser.2015.02.003

Immerzeel, D. J., P. A. Verweij, F. van der Hilst, and A. P. C. Faaij. 2014. Biodiversity impacts of bioenergy crop production: a stateof-the-art review. Global Change Biology: Bioenergy 6:183-209. http://dx.doi.org/10.1111/gcbb.12067

International Energy Agency (IEA). 2010. World energy outlook. IEA, Paris, France.

Joly, C. A., B. J. Huntley, L. M. Verdade, V. H. Dale, G. Mace, B. Muok, and N. H. Ravindranath. 2015. Biofuel impacts on biodiversity and ecosystem services. Pages 554-580 in G. M. Souza and C. A. Joly, editors. Bioenergy and sustainability: bridging the gaps. Scientific Committee on Problems of the Environment (SCOPE), Paris, France.

Jongschaap, R. E. E., W. J. Corre, P. S. Bindraban, and W. A. Brandenburg. 2007. Claims and facts on Jatropha curcas $L$. Plant Research International, Wageningen, The Netherlands.

Kuntashula, E., D. van der Horst, and S. Vermeylen. 2014. A propoor biofuel? Household wealth and farmer participation in Jatropha curcas seed production and exchange in eastern Zambia.
Biomass and Bioenergy 63:187-197. http://dx.doi.org/10.1016/j. biombioe.2014.01.051

Lawrence, D., and K. Vandecar. 2015. Effects of tropical deforestation on climate and agriculture. Nature Climate Change 5:27-36. http://dx.doi.org/10.1038/nclimate2430

Locke, A., and G. Henley. 2013. Scoping report on biofuels projects in five developing countries. Overseas Development Institute, London, UK.

Lu, H., Y. Liu, H. Zhou, Y. Yang, M. Chen, and B. Liang. 2009. Production of biodiesel from Jatropha curcas L. oil. Computers and Chemical Engineering 33:1091-1096. http://dx.doi.org/10.1016/ j.compchemeng.2008.09.012

Makungwa, S. D., A. Chittock, D. L. Skole, G. Y. Kanyama-Phiri, and I. H. Woodhouse. 2013. Allometry for biomass estimation in Jatropha trees planted as boundary hedge in farmers' fields. Forests 4(2):218-233. http://dx.doi.org/10.3390/f4020218

Meyer, M. A., T. Chand, and J. A. Priess. 2015. Comparing bioenergy production sites in the southeastern US regarding ecosystem service supply and demand. PLOS ONE 10(3): e0116336. http://dx.doi.org/10.1371/journal.pone.0116336

Millennium Ecosystem Assessment (MA). 2005. Ecosystems and human well-being: current state and trends assessment. Island Press, Washington, D.C., USA.

Mitchell, D. 2010. Biofuels in Africa: opportunities, prospects and challenges. World Bank, Washington, D.C., USA. http://dx.doi. org/10.1596/978-0-8213-8516-6

Mponela, P., C. B. L. Jumbe, and W. F. Mwase. 2011. Determinants and extent of land allocation for Jatropha curcas L. cultivation among smallholder farmers in Malawi. Biomass and Bioenergy 35:2499-2505. http://dx.doi.org/10.1016/j. biombioe.2011.01.038

National Statistical Office (NSO). 2010. Malawi statistical yearbook 2010. NSO, Zomba, Malawi.

National Statistical Office (NSO). 2011. Malawi demographic and health survey 2010. NSO, Zomba, Malawi.

Romeu-Dalmau, C., A. Gasparatos, G. von Maltitz, A. Graham, J. Almagro-Garcia, B. Wilebore, and K. J. Willis. 2016. Impacts of land use change due to biofuel crops on climate regulation services: five case studies in Malawi, Mozambique and Swaziland. Biomass and Bioenergy. http://dx.doi.org/10.1016/j.biombioe.2016.05.011

Romijn, H. A. 2011. Land clearing and greenhouse gas emissions from Jatropha biofuel on African Miombo woodlands. Energy Policy 39:5751-5762. http://dx.doi.org/10.1016/j.enpol.2010.07.041

Romijn, H., S. Heijnen, J. Rom Colthoff, B. de Jong, and J. van Eijck. 2014. Economic and social sustainability performance of Jatropha projects: results from field surveys in Mozambique, Tanzania and Mali. Sustainability 6:6203-6235. http://dx.doi. org/10.3390/su6096203

Schoneveld, G. C., L. A. German, and E. Nutako. 2011. Landbased investments for rural development? A grounded analysis of the local impacts of biofuel feedstock plantations in Ghana. Ecology and Society 16(4):10. http://dx.doi.org/10.5751/ es-04424-160410 
The Economics of Ecosystems and Biodiversity (TEEB). 2010. The Economics of Ecosystems and Biodiversity: ecological and economic foundations. Earthscan, London, UK.

Trabucco, A., W. M. J. Achten, C. Bowe, R. Aerts, J. Van Orshoven, L. Norgrove, and B. Muys. 2010. Global mapping of Jatropha curcas yield based on response of fitness to present and future climate. Global Change Biology: Bioenergy 2:139-151. http://dx.doi.org/10.1111/j.1757-1707.2010.01049.x

Van Eijck, J., H. Romijn, A. Balkema, and A. Faaij. 2014a. Global experience with Jatropha cultivation for bioenergy: an assessment of socio-economic and environmental aspects. Renewable and Sustainable Energy Reviews 32:869-889. http://dx.doi.org/10.1016/ j.rser.2014.01.028

Van Eijck, J., H. Romijn, E. Smeets, R. Bailis, M. Rooijakkers, N. Hooijkaas, P. Verweij, and A. Faaij. 2014b. Comparative analysis of key socio-economic and environmental impacts of smallholder and plantation based Jatropha biofuel production systems in Tanzania. Biomass and Bioenergy 61:25-45. http://dx. doi.org/10.1016/j.biombioe.2013.10.005

Vang Rasmussen, L., K. Rasmussen, and T. Bech Bruun. 2012. Impacts of Jatropha-based biodiesel production on above and below-ground carbon stocks: a case study from Mozambique. Energy Policy 51:728-736. http://dx.doi.org/10.1016/j.enpol.2012.09.029

von Maltitz, G. P., A. Gasparatos, and C. Fabricius. 2014. The rise, fall and potential resilience benefits of Jatropha in Southern Africa. Sustainability 6:3615-3643. http://dx.doi.org/10.3390/ $\underline{\text { su6063615 }}$

von Maltitz, G. P., A. Nickless, and R. Blanchard. 2010. Maintaining biodiversity during biofuel development. Pahes 81-118 in J. M. Amezaga, G. P. von Maltitz, and S. L. Boyes, editors. Assessing the sustainability of biofuel projects in developing countries: a framework for policy evaluation. Newcastle University, Newcastle, UK.

von Maltitz, G. P., and K. A. Setzkorn. 2013. A typology of Southern African biofuel feedstock production projects. Biomass and Bioenergy 59:33-49. http://dx.doi.org/10.1016/j.biombioe.2012.11.024

von Maltitz, G. P., and W. Stafford. 2011. Assessing opportunities and constraints for biofuel development in sub-Saharan Africa. Working Paper 58. CIFOR, Bogor, Indonesia

von Maltitz, G. P., A. Sugrue, M. B. Gush, C. Everson, G. D. Borman, and R. Blanchard. 2012. Environmental and socioeconomic considerations for Jatropha growing in southern Africa. Pages 278-306 in A. Gasparatos and P. Stromberg, editors. Socioeconomic and environmental impacts of biofuels: evidence from developing nations. Cambridge University Press, Cambridge, UK. http://dx.doi.org/10.1017/cbo9780511920899.019 